ホソ研究助成
成果報
Hosokawa Powder Technology Foundation ANNUAL REPORT

17108

\title{
界面を考慮した機能性ナノ粒子薄膜の作製 \\ Preparation of Functional Nanoparticle Films Based on Their Surfaces
}

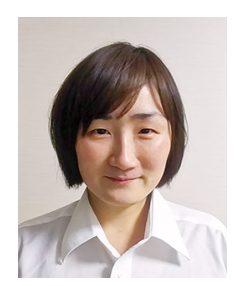

\author{
研究代表者 Research leader：高井 千加 Chika TAKAI \\ 岐皁大学工学部 助教 \\ Faculty of Engineering, Gifu University, Assistant Professor \\ E-mail: c_takai@gifu-u.ac.jp
}

抄 録

ナノ粒子をポリマーマトリックスに分散させた複合フィルムの機能性を最大限発現させるために は，所望の分散性を持つ粒子を作製することが必要である。用いるポリマーマトリックスの物性に 合わせた粒子表面を, あらかじめ把握するための指標として, ハンセン溶解性パラメーター $(H S P)$ を応用することを提案した，未改質， $\mathrm{NH}_{2}$ 改質， $\mathrm{CF}_{3}$ 改質の性質の異なる表面を持つシリカ粒子の $H S P$ 值を決め, セルロースアセテートポリマーのそれと比較し $\mathrm{NH}_{2}$ 改質が最適と判断した。実験 的にも証明でき, HSP 值の有用性を示した。

\begin{abstract}
The surface of the particles was identified using the Hansen solubility parameter $(H S P)$. From a comparison of the HSP of the unmodified and modified silica, an $\mathrm{NH}_{2}$ group is suitable for entrapment of the silica by cellulose acetate as the polymer. However, with an increase in number of the silica particles, entrapment of the silica in the polymer was prevented. Control of the phase separation rate by the lowering temperature leaded to entrapment of silica particles in the polymer network. The proposed technique is effective not only for spherical oxide particles, but also for non-oxides, various shapes and structures. Depending on particle characteristics, functional films and bulk materials for thermal insulation, light diffusion, and electro conductivity can be obtained.
\end{abstract}

研究背景と目的

ナノテクノロジーの発展とともに, 様々な材 料，構造，形状の機能性ナノ粒子の設計が可能 となった，粒子のナノサイズ化にともなって表 面物性の影響が大きくなり, マイクロサイズの
粒子とは異なる機能を発現する一方, いかに凝 集を防ぎ，本来のナノ粒子としての機能を最大 限発揮させるかが, ナノ粒子含有フィルム創製 に㧍いて非常に重要となる。

内部に空洞を持つ $100 \mathrm{~nm}$ 程度のシリカ中空 粒子をポリマーに練り込むと, 空気とほぼ同等 
の高い断熱性を持つ（Fuji M. et al., 2015）. ナ ノサイズの空洞が熱を伝えにくいためである。 さらにこの複合フイルムは，空ガラスに貼り付 けても視認性を妨げない高い可視光透過性を併 せ持つ。周知の通り,ナノ粒子は凝集しやすい. 高粘性のポリマー溶液に練り达んでも，親水性 のシリカ表面と疎水性のポリマーでは濡れ性が 悪く，粒子凝集による塊ができてしまう。そこ で，粒子表面がポリマーマトリックスと分子レ ベルで馴染みが良くなるよう, 化学的改質を行 う。物理的に距離を設けるために薄いポリマー コーティングを施してもよい. そうすれば, フィ ルム化しても透明性を維持するような高分散性 が得られる。

このように，ナノ粒子含有フィルム創製のた めには，粒子設計のみならず，分散凝集技術も 必要である. 分散技術は大別して機械的, 化学 的分散がある。前者はその名の通り，何らかの 機械的外力を加えて凝集塊をほぐす。凝集径の 大きさだけでなく，粒子形状や凝集構造などに よって, 分散装置を選択する。再凝集させない よう, 後者の化学的表面改質を施すと効果的で ある。

どのような, そして, どの程度の表面改質を すれば，用いるマトリックスへ所望の分散が可 能かを, あらかじめ（複合フィルム化する前に） 知ることができないかと考え, Hansen 溶解性 パラメーター $(H S P)$ を用いた粒子表面の指標 化を試みたので報告する。表面改質には，粒子 表面の官能基を利用したシランカップリング 剂, グラフト構造の導入や, 無機あるいは有機 薄膜の形成などが報告されている。これらの反 応は, 超臨界, マイクロ波, メカノケミカル法, プラズマ法, CVD 法, など, その後のプロセ スや効率などを考慮して適宜選択される。

大切なのは, 所望の表面物性が得られたか, である、ポリマーフィルムに練り达むのであれ ば，用いるポリマーと濡れ性がよい粒子表面が 得られたか, そして実際にそのポリマー中で改 質粒子の分散性が向上し, 機能性が向上したか, これらの相関関係を把握することが, その後の
再現性を得るうえでも非常に重要である。

フィルム化後は，ポリマー中の粒子分散性は 目視でもある程度判断が可能であるが, 紫外 可視（UV-VIS）分光光度計により可視光波長 域の透過率を測定すれば，相対的な評価はでき る. 分散状態を可視化するには（ウルトラ）ミ クロトームを用いて薄片試料を作製し，一次粒 子径が数 $\mu \mathrm{m}$ 程度までであれば光学顕微鏡, そ れ以下であれば電子顕微鏡を用いる。 三次元で 分散凝集構造を把握するには, 透過光で焦点深 度を変えて観察するのが望ましい。市販レー ザー顕微鏡や光学顕微鏡は, 付属ソフトウェア を使って三次元構造が得られるものも多い. 施 設は限られるが透過型電子顕微鏡で観察した二 次元画像を三次元に構築することも可能である.

分散状態を可視化することは技術や装置があ れば可能である。しかし，最終製品でしか分散 状態を把握できなければ作業効率が低くなる。

ポリマーを硬化させる前の前駆体溶液でレオ ロジー評価をすれば，粒子同士が強く凝集して いるのか, どの程度せん断をかければほぐれる 凝集なのか，など間接的ではあるが分散凝集状 態の情報が得られる。希釈が必要な場合が多い が, 粒度分布測定や, 水系であればゼー夕電位 からも，分散凝集の間接的な情報が得られる. 小角 $\mathrm{X}$ 線散乱 $(\mathrm{SAXS})$ を用いて液中粒子の分 散凝集構造を推測する研究も多く行われている.

粒子分散凝集構造と最終製品の機能性との相 関が取れたら，粒子表面物性の解析が必要にな る。どんな改質をすればその機能性が安定して 得られるか, は再現性を得るために非常に重要 な情報である。粒子表面に導入された改質剤の 官能基は，赤外（IR）分光分析を用い吸収スぺ クトルから確認する。粒子がシリカ $\left(\mathrm{SiO}_{2}\right)$ の

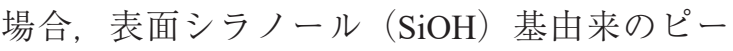
クが $3500 \mathrm{~cm}^{-1}$ 付近に現れるので, 改質剤と反 応すればこのピークが減少することを利用して 改質基導入量を定量できる。導入官能基は，空 気中で, その構造に応じて $200 \sim 400^{\circ} \mathrm{C}$ 程度 の範囲で熱分解する。熱重量分析（TG-DTA） を用い重量減少から導入改質基数を見積もるこ 
とができる．同様な原理でガスクロマトグラ フィーや質量分析と組み合わせることもでき る.

ここまでで, 最終製品の機能性を得るために 必要な表面改質量を把握できる。上述したよう に表面改質法も様々である。 反応溶媒の還流温 度で改質を行う還流法は, 特別な装置も不要で 実験室で容易に実施できる。高圧反応器（オー トクレーブ）を用いた超臨界雲囲気での反応は, 溶媒の誘電率が下がり, 粒子間隙に侵入しやす くなることから, 改質剤の導入効率は還流法よ りもよい. しかし超臨界雲囲気が材料に影響を 与える場合もあるので, 注意が必要である。そ のほか, 改質剤の沸点以上に加熱しながら気相 中で改質を行う方法もある。用いる手法や，溶 媒, 改質剤によって, また, 反応時間や温度の 条件によって, 導入される改質基量は異なる。

例えば機能性フィルムを室内で使用するな ら, 沉用性の透明性ポリマーでよいが, 室外で 使用するなら，耐候性ポリマーが必要になるだ ろう。ポリマーが変われば，適した改質剤も合 わせて変更する必要があり，そうなれば改質条 件も再考することになる，粒子を変更するケー スもあるだろう。

このように，表面改質と一言に言っても非常 に多様性に富む。手法, 条件, 溶媒などの適切 な組み合わせを，というよりは，経験に頼ると ころが大きい，しかし，もし，最終製品にする 前の, 粒子をポリマー前駆体に入れる前に, 適 した改質剤，適した改質剤導入量が分かってい たら，作業効率は格段に上がるに違いない．

\section{研 究方 法}

\section{HSP を粒子濡れ性指標へ}

溶解性パラメーターについて簡単に紹介す る. Hildebrand 博士が, 物質の溶解性パラメー ター $(S P, \delta)$ は, 自身の $1 \mathrm{~cm}^{3}$ の液体が蒸発す るために必要な蒸発熱の平方根で表現できる $\left(\delta=\left[(\Delta H-R T) / V_{\mathrm{m}}\right]^{1 / 2}, \Delta H\right.$ はモル蒸発熱, $R$ は気 体定数, $T$ は温度, $V_{\mathrm{m}}$ はモル体積）ことを示
した，SP值が近い物質同士の溶解性は高くな ることから, 例えば塗料作製において, ポリマー の溶解に適した溶剤選択に便利な指標である. その後, Hansen 博士が $S P$ 值を三次元ベクトル （分散項, 分極項, 水素結合項）で表す Hansen 溶解性パラメーター $(H S P)$ を提唱した。前者 二つのベクトルは, van der Waals 力, 双極子モー メントの力によるもので, 水素結合項はドナー, アクセプターを考慮するとさらに二つの項, つ まり合計四つのベクトルに分類できる，HSP 值もSP值と同様, “值が似ているものは似て いるものを溶解する”という単純な考え方であ るが，三つ，または四つのベクトルを用いるこ とで, 何の力が㗢いてお互いの溶解性を高めて いるのかを分析できることが，SP 值と異なる 非常に優位な点である。

この HSP 值を固体粒子の分散性指標に用い る場合, “HSP 值が似ているものは似ているも のを分散する”と言い換えることができる，既 に酸化物, 炭化物, 粘土などのナノサイズ, マ イクロサイズの粒子について, 分散性のよい溶 媒を選択する, あるいは粒子の HSP 值を求め る報告もされている（Süß S. et al., 2018）.

固体粒子の $H S P$ 值の求め方の一例を紹介し たい。 三つのべクトルで表した三次元空間 (Hansen 空間) に, HSP 值既知の有機溶媒をプ ロットする。これらの有機溶媒に対し, 対象と する粒子をよく分散する溶媒か否かを何らかの 方法で判断する。よく分散する溶媒のプロット をできるだけ取り入れ，否の溶媒のプロットを できるだけ排除するように球（Hansen 球）を 描く。この Hansen 球の中心が対象粒子の HSP 值となる. Hansen 球は, 山本博志氏, Steven Abott 教授が共同開発した HSPiP ソフトウェア を用いて描くことができる。

分散溶媒か否かを判断するにはいくつかの方 法がある。例えばLUM 社の LUMiSizer は, 分 散液を遠心場で強制的に沈降させ，その上澄み の透過率の経時変化をスペクトル表示すること ができる。ここから溶媒の粘度や透過率を考慮 した規格化沈降時間を計算し，任意の䦐值より 
沈降時間が長ければ分散溶媒と判断する。分散 液の凝集径分布を測定して，同様に閾値を設け てもよい. 卓上型核磁気共鳴 (NMR) も，短 時間で粒子表面と溶媒との濡れ性を評価するこ とができる。

$H S P$ 值既知の溶媒は, $20 \sim 30$ 種程度を用い ることが推奨される．粒子の HSP 值が全く見 当つかない場合，できるだけ多様性のある $H S P$ 值を持つ溶媒を選択する。 また, Hansen 球内, または外に，分散溶媒と否の溶媒がどちらも 入ってしまうことがある。このエリアのベクト ルを持つ溶媒を増やして球の境目を正確に求め ることで，より正確な HSP 值を求めることが できる.

\section{研 究成果}

粒子を三次元網目状に配列させると, 粒子の 材質によって, 光拡散性や導電性を発現する機 能性薄膜となる。これを, 貧溶媒誘起相分離法 （NIPS）を応用することで，得ることができる (Takai C. et al., 2014). NIPS は，フィルターな どに用いるポリマー多孔質膜を作製するため に, ポリマー基材, 良溶媒, 貧溶媒の三成分溶 液を作り, これを出発溶液として良溶媒を揮発 させると, ポリマーと貧溶媒が配合や性質に応 じて三次元構造に相分離する。つまり, ポリマー が網目構造を作り, その網目構造の中に貧溶媒 が池のように存在した構造となる。何らかの方 法で貧溶媒を除去すると, 三次元ポリマー網目 構造ができる，粒子が出発原料中に存在してい たら，このポリマー網目構造をガイドとして， 粒子を並べることができるだろうと考えた。

本手法の有利な点は, まず簡便なことである. 三成分溶液を基板等にコーティングするのみで よく, 大掛かりな装置も不要である。粒子がポ リマー（ここではセルロースアセテート）と濡 れ性がよければ，ポリマーに取り达まれて三次 元構造を作るだろう。そのために，どのような 粒子表面物性を作孔ばよいか，HSP 值を使っ て検討した。
粒子はシリカを用いた，今までに，種々表面 改質の経験があったためである。改質剤はシラ ンカップリング剂を用い, 官能基はアミノ $\left(\mathrm{NH}_{2}\right)$ 基とトリフルオロメチル $\left(\mathrm{CF}_{3}\right)$ 基を選 択した。 未改質粒子は $\mathrm{SiOH}$ の親水性, $\mathrm{NH}_{2}$ 基 改質により極性, $\mathrm{CF}_{3}$ 基改質により疎水性表面 ができていることになる。これらを各々 26 種 類の溶媒に分散させ, LUMiSizer を用いて溶媒 を分類した。 その結果, HSP 值は, 未改質で $20.79, \mathrm{NH}_{2}$ 改質で 21.83, $\mathrm{CF}_{3}$ 改質で 19.86 となっ た。これだけでは優位な差があるとは言えない が, 水素結合項 $\left(\delta_{\mathrm{H}}\right)$ を見ると, 5.71, 8.06, 3.65 となっており，基材に用いたセルロースアセ テートの $\delta_{\mathrm{H}}$ が 7.41 であることを考えると, $\mathrm{NH}_{2}$ 改質することで粒子表面が基材に近づいた と言える. 各々の未改質, 改質粒子の水蒸気吸 着等温線から, 粒子表面の一層目に吸着する水 の量を試算すると, $\mathrm{NH}_{2}$ 改質粒子が最も多く, $\delta_{\mathrm{H}}$ が大きく減少したことが妥当であることを 裏付けており, 改質粒子に対しても, 分散媒と の濡れ性指標化として HSP 值が使える可能性 が高いことを示唆している.

$\mathrm{NH}_{2}$ 基改質したシリカをセルロースアセテー トに対して $30 \%$ となるよう加え, NIPS 法によ り三次元多孔膜を作製した。未改質粒子は，七 ルロースアセテートの外に排出されるのに対し て, $\mathrm{NH}_{2}$ 基改質粒子は内部に取り达まれている ことが分かる。 NIPS 法を用いる場合, 良溶媒 の揮発とともに溶液の粘性が上がる，粒子濃度 の増加も同様である. 粘度の増加は, 粒子の移 動を妨げるため, 厳密には HSP 值のみを合わ せれば三次元多孔膜を作れるというわけではな いが，HSP 值を合わせなければ他の条件を制 御しても三次元多孔膜は作れない.

本報告では HSP 值を用いて粒子表面の濡れ 性を指標化することを試みた。検討事項は残っ ている段階ではあるが，HSP值が，ポリマー マトリックスへ良分散する粒子表面を知る手段 として有効であることを示すことができたと考 えている. 


\section{謝辞}

本研究の遂行にあたり助成いただいた公益財 団法人ホソカワ粉体工学振興財団に感謝の意を 表する.

\section{参考文献}

Fuji M., Takai C., Watanabe H., Fujimoto K., Improved transparent thermal insulation using nano-spaces, Advanced

\section{外部 発表成果}

\section{論文発表}

1. Chika Takai-Yamashita, Hidenori Nagamine, Yuki Nakashima, Peng Bo, Masayoshi Fuji, Manipulating the chemical affinity and kinetics of 3D silica particle network via the phaseseparation technique, Advanced Powder Technology, 29 (2018) 3062-3069.

https://doi.org/10.1016/j.apt.2018.08.004

2. Chika Takai-Yamashita, Emiko Sato, Masayoshi Fuji, NMR as a tool to characterize the aggregation structure of silica nanoparticles in a liquid, KONA Powder and Particle Journal, (2020). https://doi.org/10.14356/kona.2020012

\section{口頭・ポスター発表}

1. Chika Takai, Masayoshi Fuji, "Design of Nano/ Microstructures of Hollow, Skeletal, and Porous
Powder Technology, 26 (2015) 857-860.

http://dx.doi.org/10.1016/j.apt.2015.02.012

Süß S., Sobisch T., Peukert W., Lerche D., Segets D., Determination of Hansen parameters for particles: A standardized routine based on analytical centrifugation, Adv. Powder Technol., 29 (2018) 1550-1561. https://doi.org/10.1016/j.apt.2018.03.018

Takai C., Tamura A., Fuji M., Synthesis of a silver nanoparticle network induced by a micro-phase separation, Advanced Powder Technology, 25 (2014) 621-624. https://doi.org/10.1016/j.apt.2013.10.002

Particles", World Congress on Powder Technology (WCPT8) (Florida, USA, April 22-26, 2018) as keynote speaker

2. Chia Takai, Hidenori Nagamine, Masayoshi Fuji, "Manipulating the chemical affinity and Kinetics of 3D Silica Nanoparticle Networking via the Phase-Separation Technique”, International Powder and Nanotechnology Forum (IPNF) 2018 (Frankfurt, Germany, July 12-13, 2018)

3. Chika Takai, Kyoichi Fujimoto, Masayoshi Fuji, "Improved Optical Property of Skeletal Silica Nanoparticle/Polymer Composite Film”, $12^{\text {th }}$ International Conference on Ceramic Materials and Components for Energy and Environmental Applications (CMCEE2018) (Suntec, Singapore, July 22-27, 2018)

4. 高井 千加, 長嶺 英範, 藤 正督, “ミクロ相 分離を用いた三次元シリカ粒子網目構造の 形成”, 第 56 回粉体に関する討論会, (Hamamatsu, Sept. 25-27, 2018). 